\title{
Assessment of the microbiological quality of pattern minas cheese commercialized in Uberlândia and Patos de Minas, Minas Gerais*
}

\section{Avaliação microbiológica de queijo minas padrão comercializado em Uberlândia e Patos de Minas, Minas Gerais}

\author{
Aryele Nunes da Cruz Encide Sampaio ${ }^{1}$ (D); Bruna Godoi Castro ${ }^{1}$; Fernanda Raghiante ${ }^{1}$; \\ Felipe Chaimsohn Gonçalves da Silva ${ }^{1}$; Everton Cruz de Azevedo ${ }^{1}$; Jéssica Fernandes de Oliveira ${ }^{1}$; \\ Marise Santiago Velame ${ }^{1}$; Lorena Natalino Haber Garcia ${ }^{1}$; José Paes de Almeida Nogueira Pinto ${ }^{1}$; \\ Eduardo Delbon Baldini ${ }^{1}$; Fábio Sossai Possebon ${ }^{1}$; Germano Biondi ${ }^{1}$; Juliano Gonçalves Pereira ${ }^{1}$; \\ Otávio Augusto Martins ${ }^{1}$
}

${ }^{1}$ Universidade Estadual Paulista "Júlio de Mesquita Filho", Faculdade de Medicina Veterinária e Zootecnia, Departamento de Produção Animal e Medicina Veterinária Preventiva, Botucatu - SP, Brazil

\begin{abstract}
Pattern minas cheese is a product developed with pasteurized milk, fermented with mesophilic cultures, and with the final addition of rennet. This cheese undergoes an artisanal maturation process and possesses a firm shell of yellowish color and striking and acidic flavor. Our study objective was to evaluate the microbiological quality of pattern minas cheese. We collected 40 samples from two micro regions (Uberlândia and Patos de Minas) of the Triângulo Mineiro and Alto Paranaíba mesor regions of the State of Minas Gerais, Brazil. The microbiological test results were recorded as counts of enterobacteria, Escherichia coli, coliforms at $35^{\circ} \mathrm{C}$, coagulase-positive Staphylococcus and Salmonella spp. In the Patos de Minas micro region, the results were $45 \%, 35 \%, 20 \%$, and $20 \%$ higher than $10^{3} \mathrm{CFU} / \mathrm{g}$ for the counts of enterobacteria, Escherichia coli, coliforms at $35^{\circ} \mathrm{C}$, and Staphylococcus coagulase-positive, respectively. Five percent of the analyzed samples were positive for Salmonella spp. in the Uberlândia micro region. Based on the findings of the microbiota in the cheese analyzed from the micro regions (Uberlândia and Patos de Minas), we concluded that the hygiene conditions in the manufacturing, handling, transport, and storage stages were precarious, requiring the implementation of Good Manufacturing Practices (GMP) systems, including Hazard Analysis and Critical Control Points (HACCP).
\end{abstract}

Keywords: Hygiene. Quality. Pattern Minas Cheese. Microbiology.

\section{RESUMO}

O queijo minas padrão é um produto elaborado com leite pasteurizado, fermentado com culturas mesófilas e adição de coalho. Esse queijo passa por um processo de maturação artesanal, possui uma casca firme de cor amarelada e sabor ácido. O presente trabalho avaliou a qualidade microbiológica de queijo minas padrão comercializado em duas microrregiões (Uberlândia e Patos de Minas) da mesorregião do Triângulo Mineiro e Alto Paranaíba do estado de Minas Gerais, Brasil. Foram examinadas 40 amostras de queijo. Os ensaios microbiológicos foram contagens de enterobactérias, Escherichia coli, coliformes a $35^{\circ} \mathrm{C}$, Staphylococcus coagulase positiva e pesquisa de Salmonella spp. Na microrregião de Patos de Minas, os resultados foram de $45 \%, 35 \%, 20 \%$ e $20 \%$ superiores a $10^{3} \mathrm{CFU} / \mathrm{g}$ para as contagens de enterobactérias, Escherichia coli, coliformes a $35^{\circ} \mathrm{C}$ e Staphylococcus coagulase positiva, respectivamente. Cinco por cento das amostras analisadas foram positivas à pesquisa de Salmonella spp. Considerando a microrregião analisada (Uberlândia e Patos de Minas), a conclusão obtida foi que na região estudada, as condições de higiene nas etapas de fabricação, manuseio, transporte e armazenamento do queijo minas padrão são precárias, sendo necessária a implementação de sistemas de Boas Práticas de Fabricação (GMP), incluindo Análise de Perigos e Pontos Críticos de Controle (HACCP).

Palavras-chave: Higiene. Qualidade. Queijo Minas Padrão. Microbiologia.

*This article was adapted from the abstract published in: Castro BG, Garcia LNH, Encide Sampaio ANC, Silva FC, Azevedo EC, Velame MS, Pinto JP, Baldini ED, Possebon FS, Germano B, Martins OA. Qualidade microbiológica de queijo minas padrão[resumen]. In: Libro de Resúmenes del 24. Congreso Latinoamericano de Microbiología, 14-15 nov. 2018; Santiago, Chile. p. MA340-476. 


\section{Correspondence to:}

Aryele Nunes da Cruz Encide Sampaio

Universidade Estadual Paulista "Júlio de Mesquita Filho",

Faculdade de Medicina Veterinária e Zootecnia, Departamento

de Produção Animal e Medicina Veterinária Preventiva

Rua Prof. Doutor Walter Mauricio Correa, $\mathrm{s} / \mathrm{n}$

CEP: 18618-681, Botucatu - SP, Brazil

e-mail: aryelesampaio_@hotmail.com

Received: October 10, 2020

Approved: March 3, 2021

How to cite: Sampaio ANCE, Castro BG, Raghiante F, Silva FCG, Azevedo EC, Oliveira JF, Velame MS, Garcia LNH, Pinto JPAN, Baldini ED, Possebon FS, Biondi G, Pereira JG, Martins OA. Assessment of the microbiological quality of pattern minas cheese commercialized in Uberlândia and Patos de Minas, Minas Gerais. Braz J Vet Res Anim Sci. 2021;58:e175850. https://doi.org/10.11606/issn.16784456.bjvras.2021.175850

\section{Introduction}

The minas cheese and their most important varieties, minas frescal and pattern minas are among the topmost produced cheeses in Brazil. In the state of Minas Gerais, the cheeses most produced include mozzarella, cheese minas (pattern and fresh), and curd cheese. Most of the state dairy products are concentrated in the South (36.5\%), Zona da Mata (17\%), Triângulo Mineiro and Alto Paranaíba (14.8\%), and Metalúrgica (14.4\%) (Martins, 2001).

According to the technical regulation of the identity and quality of animal products (Brasil, 2017), pattern cheese is defined as raw or semi-processed cheese obtained by coagulating pasteurized milk with rennet or other appropriate coagulating enzymes, or both, supplemented or not, by the action of specific lactic acid bacteria, followed by obtaining the curd, desorbed, mechanically pressed, salted, and matured.

The process of artisanal maturation occurs for approximately 30 days, with the formation of a firm yellowish color and a marked acidic flavor, making it receive denominations such as cured minas, pressed minas, pattern minas, and pasteurized minas, according to the region (Instituto Nacional de Metrologia, Qualidade e Tecnologia, 2006).

Cheese is often involved in the spread of foodborne pathogens. Microbiological contamination is of great relevance to the industry, due to economic losses and impact on public health through the transmission of food-borne diseases (Feitosa et al., 2003).

Because cheese is a highly manipulated product, it is highly susceptible to microbiological contamination. The contamination is aggravated with the use of raw milk, which is processed without any thermal treatment, without any observances of good manufacturing practices, or an adequate technology for product preparation and its minimum maturation time (Pinto et al., 2009). Intrinsic and extrinsic factors such as temperature, $\mathrm{pH}$, and water activity favor the growth of pathogenic microorganisms (Pinto, 1996).

Because of poor hygienic conditions during production, cheese may be exposed to pathogenic bacterial contamination from infected persons or animals and feces of contaminated individuals. This poses a serious public health hazard by causing a multiplication of the microorganism and/or production toxins leading to a severe infection or food poisoning. Bacteria, due to their diversity and pathogenesis, are the most important group associated with foodborne diseases (Pinto, 1996).

The pathogenic microorganisms investigated in the present paper were Salmonella spp., Escherichia coli, and Staphylococcus aureus, which are per Câmara et al. (2000), as the most important pathogenic microorganism in the subject of foodborne diseases.

The group of coliform bacteria also plays a major role in foodborne diseases by colonizing the intestinal tract of humans and animals. These bacteria act as indicators for the sanitary quality of food because they represent contamination at various stages of the manufacturing process (Oliveira et al., 2008; Vieira et al., 2008).

This study objective was to evaluate the microbiological quality of the pattern minas cheese produced in the Uberlândia and Patos de Minas micro regions of the Triângulo Mineiro and Alto Paranaíba mesor region of the State of Minas Gerais, Brazil, investigating the presence of pathogenic microorganisms and contamination indicators in this kind of cheese.

\section{Material and Methods}

A total of 40 pattern minas cheese samples were collected from the Uberlândia $(n=20)$ and Patos de Minas $(n=20)$ micro-regions of the Triângulo Mineiro and Alto Paranaíba mesor regions of the State of Minas Gerais, Brazil. The samples were collected from January to July 2015. The cheeses, transported at $4^{\circ} \mathrm{C}$, were sent to the Department of Veterinary Hygiene and Public Health - Faculty of Veterinary Medicine and Animal Science, Paulista State University "Júlio de Mesquita Filho" (UNESP), Campus of Botucatu, São Paulo, Brazil for the analysis of coliform counts at $35^{\circ} \mathrm{C}$, Escherichia coli, enterobacteria, coagulasepositive Staphylococcus, and a search for Salmonella sp. 


\section{Preparation of the samples and their dilutions}

For the analyses, 25 grams of the sample was weighed and homogenized with $225 \mathrm{~mL}$ of sterile $0.1 \%$ saline solution in a sterile plastic bag. From the initial dilution, serial dilutions were prepared using $0.1 \%$ saline.

\section{Coliform counts at $35^{\circ} \mathrm{C}$ and Escherichia coli}

The serial dilutions of the samples were selected, and $1 \mathrm{~mL}$ aliquots were inoculated into Petri film ${ }^{\text {Tx }}$ plates and incubated at $35^{\circ} \mathrm{C}$ for $48 \mathrm{~h}$ for counting Escherichia coli $(3 \mathrm{M})$. The red colonies, associated with gas bubbles, were counted as coliforms at $35^{\circ} \mathrm{C}$, and the ones with bluetcolored colonies with gas bubbles, were labeled as E. coli. The results were expressed in colony-forming units/g (American Public Health Association, 1992).

\section{Enterobacteria Count}

The serial dilutions of the samples were selected, and $1 \mathrm{~mL}$ aliquots were inoculated into Petri film ${ }^{\mathrm{Th}}$ plates and incubated at $35^{\circ} \mathrm{C}$ for $48 \mathrm{~h}$ to count Enterobacteria (3M). The red colonies surrounded by a yellowish zone were counted as enterobacteria. The results were expressed in colony-forming units per gram (American Public Health Association, 1992).

\section{Coagulase-positive Staphylococcus counts}

The serial dilutions of the samples were selected, and a $0.1 \mathrm{~mL}$ aliquot was inserted into the Petri dish containing Baird-Parker agar spreading the inoculum with the aid of Drigalsky's handle. The plates were inverted and incubated at $35^{\circ} \mathrm{C}$ for $48 \mathrm{~h}$. Three to five typical and atypical colonies were transferred to the brain heart infusion broth (BHI) and incubated at $35^{\circ} \mathrm{C}$ for $24 \mathrm{~h}$. The broth, which presented turbidity in the coagulase test using EDTA-plasma coagulase and led to the formation of a clot (American Public Health Association, 1992), was considered as positive for Staphylococcus.

\section{Search for Salmonella spp.}

Two hundred fifty milligrams of the sample were weighed into a sterile bag. Then, $225 \mathrm{~mL}$ of preselection broth and buffered peptone water (BPW), was added and the sample was homogenized and incubated at $37 \pm 1^{\circ} \mathrm{C}$ for $24 \mathrm{~h}$. After $24 \mathrm{~h}, 0.1 \mathrm{~mL}$ aliquot was transferred to $10 \mathrm{~mL}$ of Rappaport Vassiliadis broth (VR) and $1 \mathrm{~mL}$ to $10 \mathrm{~mL}$ of tetrathionate broth supplemented with $0.2 \mathrm{~mL}$ iodine iodide and incubated at $45 \pm 1^{\circ} \mathrm{C}$ for $2 \mathrm{~h}$. Differential plating was carried out by sowing, through streaks, using the broths containing xylose lysine deoxycholate agar (XLD) and plated on a bismuth sulfite agar (BS) and incubated at $37 \pm 1^{\circ} \mathrm{C}$ for $24 \mathrm{~h}$. From the typical colonies, three to five typical and atypical colonies were inoculated in an inclined tube containing triple sugar iron (TSI) and were incubated at $37 \pm 1^{\circ} \mathrm{C}$, following the same procedure as with lysine iron agar. Serological confirmation with polyvalent antiserum was used to detect somatic (poli O) and flagellar (poli $\mathrm{H}$ ) antigens, confirming the presence of Salmonella spp. through the formation of lumps (American Public Health Association, 1992).

\section{Results and Discussion}

The results obtained in this study were compared with the microbiological standards determined by RDC 12 of the National Health Surveillance Agency (Brasil, 2001) on January 2, 2001.

Ordinance No. 146 of March 7, 1996, of the Ministry of Agriculture, Livestock, and Supply (MAPA) was used to compare the population of total coliforms $\left(35^{\circ} \mathrm{C}\right)$ (Brasil, 1996).

The microorganisms analyzed belong to the group of mesophilic aerobes. The counting of this group of bacteria is usually performed to assess the hygienic-sanitary conditions of the industry. High counts of these microorganisms in food may indicate that the food was prepared with highly contaminated raw materials, unsatisfactory processing from the sanitary point of view, or stored under inadequate conditions of time and temperature (Leite et al., 2000; Pereira, 2007; Reis et al., 2006).

For cheese making, it is important to select the raw material to be used through the microbiological and physical-chemical selection of milk, free of impurities. The higher the microbiological quality of the cheese, the greater its production profitability (Paula et al., 2009).

The results obtained for the Escherichia coli count showed that it was above the count that was established in legislation (7/20 in Uberlândia and 4/20 in Patos de Minas). Escherichia colibelongs to the Enterobacteriaceae family. The presence of enterobacteria may indicate the possibility of the presence of pathogenic bacteria such as those of the genus Salmonella spp., pathogens responsible for numerous cases of food infection outbreaks (Franco \& Landgraf, 2005). E. coli is the main representative of the fecal origin indicators. E. coli can live in the intestinal tract of humans and warm-blooded animals, and its presence in high counts may represent a risk to consumer health (Amorim et al., 2014; Franco \& Landgraf, 2005). The presence of coliform bacteria in food is interpreted as an indicator of contamination and poor 
Table 1 - Proportion ( $\geq 10^{3}$ or $<10^{3} /$ total samples) of enterobacterias, Escherichia coli, coliforms at $35^{\circ} \mathrm{C}$ higher than $10^{3} \mathrm{CFU} / \mathrm{g}$, and coagulase-positive Staphylococcus in the pattern minas cheese from the micro regions of Uberlândia and Patos de Minas in the State of Minas Gerais, Brazil, observing higher counts than established in legislation. The samples were collected from January to July 2015

\begin{tabular}{cccccc}
\hline Micro regions & CFU/g & enterobacterias & E. coli & Total coliforms & S. coagulase + \\
\hline Uberlândia & $\geq 10^{3}$ & $11 / 20$ & $6 / 20$ & $7 / 20$ & $5 / 20$ \\
& $<10^{3}$ & $9 / 20$ & $14 / 20$ & $13 / 20$ & $15 / 20$ \\
Patos de Minas & $\geq 10^{3}$ & $9 / 20$ & $7 / 20$ & $4 / 20$ & $4 / 20$ \\
& $<10^{3}$ & $11 / 20$ & $13 / 20$ & $16 / 20$ & $16 / 20$ \\
\hline
\end{tabular}

Table 2 - Proportion (absence or presence/total samples) of Salmonella ssp. in pattern minas cheese from the micro regions of Uberlândia and Patos de Minas in the State of Minas Gerais, Brazil. The samples were collected from January to July 2015

\begin{tabular}{ccc}
\hline \multirow{2}{*}{ Micro regions } & \multicolumn{2}{c}{ Search for Salmonella sp. } \\
\cline { 2 - 3 } & Absence & Presence \\
\hline Uberlândia & $19 / 20$ & $1 / 20$ \\
Patos de Minas & $20 / 20$ & $0 / 20$ \\
\hline
\end{tabular}

hygienic-sanitary conditions, indicating a possible presence of enteric pathogens (Cardoso et al., 2005), which are easily destroyed by heat, unable to survive the thermal treatment of pasteurization (Silva et al., 2007). There were no tests performed to analyze the thermotolerant coliforms $\left(45^{\circ} \mathrm{C}\right)$ in the respective samples. However, this group was represented by Escherichia coli. Brant et al. (2007) found that $80 \%$ of the analyzed samples from the artisanal minas of Serro presented with a coliform count above $5 \times 10^{3} \mathrm{CFU} / \mathrm{g}$, at $35^{\circ} \mathrm{C}$, and were considered unfit for consumption. Of the total pattern minas cheese analyzed, $27.5 \%$ presented a coliform population at $35^{\circ} \mathrm{C}$ higher than $10^{3} \mathrm{CFU} / \mathrm{g}$ (Table 1 ).

According to Table 2, 1/20 of the samples obtained in Uberlândia (MG) presented with Salmonella spp. contamination, which is beyond the standard established by Resolution RDC 12 on January 2, 2001. However, there was a total absence of the pathogen in the samples of Patos de Minas (MG) (Brasil, 2001). The lower competition capacity of Salmonella spp. concerning the coliform group and coagulase-positive Staphylococcus spp. may be the reason for the absence of the pathogen (Brant et al., 2007).

\section{Conclusion}

Considering the results of this study, $97.5 \%$ of the analyzed samples were within the standard established by RDC 12 of January 2, 2001, of Anvisa, revealed as an absence of Salmonella spp. in $25 \mathrm{~g}$ of sample.

However, $66.25 \%$ of the samples presented contamination above the limit allowed by the legislation, making the pattern minas cheese from the micro regions of Uberlândia and Patos de Minas unfit for human consumption. Thus, this indicates that the hygiene conditions in the stages of manufacture, handling, transportation, and storage were poor. Therefore, it is necessary for industries to implement Good Manufacturing Practices (GMP) systems, including Hazard Analysis and Critical Control Points (HACCP), to avoid possible contamination and further emphasizing the need for timely inspection of pattern minas cheese production.

\section{Conflict of Interest}

The authors state that they have no conflicts of interest to declare.

\section{Ethics Statement}

Not applicable.

\section{Acknowledgements}

Not applicable.

\section{References}

American Public Health Association - APHA. Committe on Microbiologycal Methods for Foods. Compendiun of methods for the microbiologycal examination of foods. Washington: APHA; 1992.

Amorim ALBC, Couto EP, Santana AP, Robeiro JL, Ferreira MA. Avaliação da qualidade microbiológica de queijos do tipo Minas padrão de produção industrial, artesanal e informal. Rev Inst Adolfo Lutz. 2014;730(4):364-7. http:// dx.doi.org/10.18241/0073-98552014731628.

Brant LMF, Fonseca LM, Silva MCC. Avaliação da qualidade microbiológica do queijo-de-minas artesanal do Serro-MG. Arq Bras Med Vet Zootec. 2007;59(6):1570-4. 
Brasil. Ministério da Agricultura e do Abastecimento. Portaria no 146, de 7 março de 1996 [Internet]. Diário Oficial da União; Brasília; 1996 Mar 11 [cited 2019 May 20]. Available from: https://wp.ufpel.edu.br/inspleite/files/2016/03/Portarian\%C2\%B0-146-de-7-de-mar\%C3\%A7o-de-1996.pdf.

Brasil. Agência Nacional de Vigilância Sanitária. Resolução RDC no 12, de 2 de janeiro de 2001 [Internet]. Diário Oficial da União; Brasília; 2001 Jan 10 [cited 2019 May 20]. Available from: http://portal.anvisa.gov.br/documents/33880/2568070/ RDC_12_2001.pdf/15ffddf6-3767-4527-bfac-740a0400829b.

Brasil. Ministério da Agricultura, Pecuária e Abastecimento. Decreto $n^{\circ}$ 9.013, de 29 de março de 2017 [Internet]. Diário Oficial da União; Brasília; 2017 Mar 29 [cited 2019 May 20]. Available from: http://www.planalto.gov.br/ccivil_03/_ ato2015-2018/2017/decreto/d9013.htm.

Câmara SAV, Amaral GB, Muller MT, Silveira KCS, Almeida TN, Medeiro CF. Avaliação microbiológica de queijo tipo minas frescal artesanal, comercializados no mercado municipal de Campo Grande, Mato Grosso do Sul. Hig Aliment. 2000;16(101):32-6.

Cardoso ALSP, Castro AGM, Tessari ENC, Baldassi L, Pineiro ES. Pesquisa de Salmonella sp coliformes totais, coliformes fecais, mesófilos, em carcaças e cortes de frango. Hig Aliment. 2005;19(128):144-50.

Feitosa T, Borges MF, Nassu RT, Azevedo ÉHF, Muniz CR. Pesquisa de Salmonella sp., Listeria sp. e microrganismos indicadores higiênico-sanitários em queijos produzidos no Estado do Rio Grande do Norte. Food Sci Technol. 2003;23:162-5.

Franco BDGM, Landgraf M. Microbiologia dos alimentos. São Paulo: Atheneu; 2005.

Reis JA, Hoffmann P, Hoffmann FL. Ocorrência de bactérias aeróbias mesófilas, coliformes totais, fecais e Escherichia coli, em amostras de águas minerais envasadas, comercializadas no município de São José do Rio Preto, SP. Hig Aliment. 2006;20(145):109-15.

Instituto Nacional de Metrologia, Qualidade e Tecnologia - INMETRO. Informação ao consumidor [Internet]. 2006 [cited 2019 May 20]. Available from: http://www.inmetro. gov.br/consumidor/produtos/queijo_Minas.asp.
Leite AFS Jr, Florentino ER, Oliveira NEB, Sá SNE, Torrano ADM. Qualidade microbiológica do queijo de coalho comercializado à temperatura ambiente ou sob refrigeração, em Campina Grande - PB. Hig Aliment. 2000;14:53-9.

Martins E. Patrimônio de Minas. Jornal Estado de Minas; Belo Horizonte; 2001 Dec:14-17.

Oliveira CAF, Moreno JFG, Mistier L, German PML. Características físico-químicas e microbiológicas de queijos minas frescal e mussarela. Pirassununga; 2008.

Paula JCJ, Carvalho AF, Furtado MM. Princípios básicos de fabricação de queijo: do histórico à salga. Rev. Inst. Latic. Cândido Tostes. 2009;367/368:19-25.

Pereira RB. Caracterização microbiológica de alguns tipos de queijos regionais brasileiros [thesis]. Belo Horizonte: Instituto de Ciências Biológicas, Universidade Federal de Minas Gerais; 2007. 31 p.

Pinto A. Doenças de origem microbiana transmitidas pelos alimentos [Internet]. Araras: UFSCar; 1996 [cited 2019 May 20]. Available from: https://web-06.ufscar.br/araras/ pessoal/vico-folder/vico/arquivos/ma/doencas-de-origemmicrobiana-transmitidas-pelos-alimentos.pdf.

Pinto MS, Ferreira CLF, Martins JM, Teodoro VAM, Pires ACS, Fontes LBA, Vargas PIR. Segurança alimentar do queijo Minas Artesanal do Serro, Minas Gerais, em função da adoção de boas práticas de fabricação. Pesqui Agropecu Trop. 2009;39(4):342-7.

Silva N, Junqueira VCA, Silveira NFA, Taniwaki MH, Santos RFS, Gomes RAR. Manual de métodos de análise microbiológica de alimentos. São Paulo: Varela; 2007.

Vieira KP, Ledesma MM, Rosa CM, Hassegawa RH. Contaminação de queijo minas frescal por bactérias patogênicas: um risco à saúde. ConScientiae Saúde. 2008;2(7):201-6.

Financial Support: This project received financial support from Serviço de Orientação à Alimentação Pública and Fundação de Apoio aos Apoio aos Hospitais Veterinários da UNESP. 